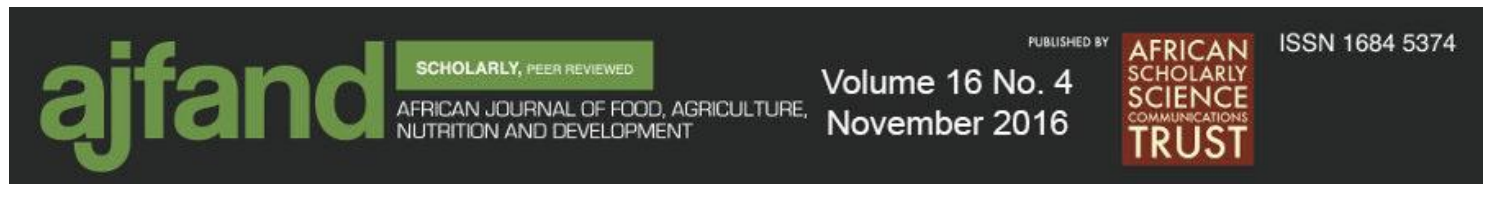

DOI: 10.18697/ajfand.76.13900

\title{
ASSESSMENT OF APPARENT EFFECTIVENESS OF CHEMICAL EGG DISINFECTANTS FOR IMPROVED ARTIFICIAL HATCHING IN Oreochromis karongae (PISCES: CICHLIDAE)
}

Valeta $\mathrm{J}^{1 *}$, Likongwe $\mathrm{J}^{1}$, Kassam $\mathrm{D}^{1}$, Maluwa $\mathrm{A}^{\mathbf{2}}$ and $\mathrm{B}$ Chirwa ${ }^{3}$

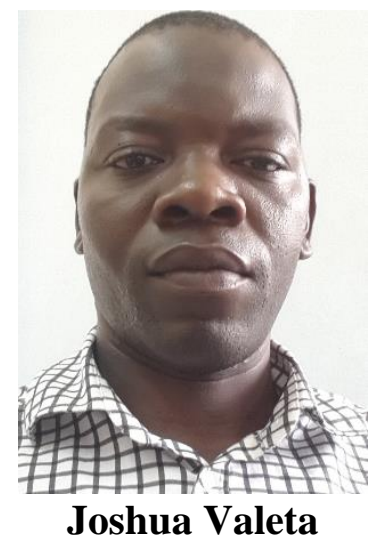

*Corresponding author email: jvaleta32@gmail.com

${ }^{1}$ Lilongwe University of Agriculture and Natural Resources, Bunda Campus, P.O. Box 219, Lilongwe, Malawi

${ }^{2}$ Malawi University of Science and Technology, P.O. Box 5196, Limbe, Malawi

${ }^{3}$ National Aquaculture Center, P.O. Box 44, Domasi, Malawi 


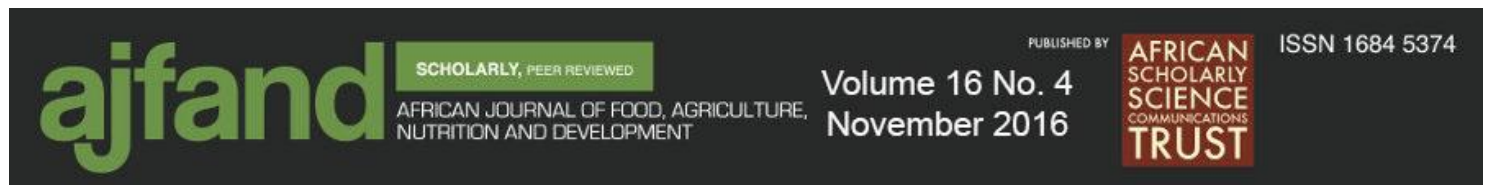

\begin{abstract}
Oreochromis karongae is one of the three key Tilapia species locally known as 'Chambo' which is endemic to Lake Malawi. The species is favored by consumers and due to high demand its catches have significantly declined over time. Aquaculture holds the potential to supplement catches as well as produce seed for restocking purposes. However, seed production of O.karongae in artificial hatcheries has registered little success due to high egg and fry mortalities. Therefore, a study was conducted to compare the apparent effectiveness of three chemical egg disinfectants in an attempt to improve hatching success and reduce fry mortality in $O$. karongae in an artificial re-circulating incubation system at the National Aquaculture Center, Domasi, Malawi. Batches of 200 stage II eggs were immersed for 5 minutes in $50 \mathrm{ml}$ solutions of (1) $50 \mathrm{mg} / \mathrm{l}$ Potassium Permanganate, (2) $500 \mathrm{mg} / \mathrm{l}$ Formalin, (3) $1000 \mathrm{mg} / \mathrm{l}$ Sodium Chloride, (4) 5000mg/l Sodium Chloride, while treatment (5) was a control without any chemical treatment. Each treatment was replicated three times in $1.2 \mathrm{~L}$ plastic incubation jars with continuous water flow rate of $0.17 \mathrm{l} / \mathrm{s}$ operated at $10 \%$ daily water replacement. There was significantly low total mortality and high hatchability in treatments (1), (2) and (3) than (4) and (5) $(\mathrm{p}<0.05)$. The results provided evidence that pre-incubation egg treatment using chemicals has potential to significantly reduce mortalities and increase fry production in an artificial re-circulating incubation system. It is recommended, based on the findings that lower concentrations of sodium chloride, being a safer and less toxic chemical can be used for disinfecting O.karongae eggs. Future studies should focus on undertaking a toxicity test with various levels of the chemical disinfectants to identify optimum doses. This should be coupled with microbiological assays to validate the apparent effectiveness found in this study and identify the key microbial species that are responsible for mortalities during incubation of O.karongae eggs in a re-circulating system.
\end{abstract}

Key words: Egg, disinfectants, incubation, recirculation, hatchability, egg treatment, mortality, Oreochromis karongae 


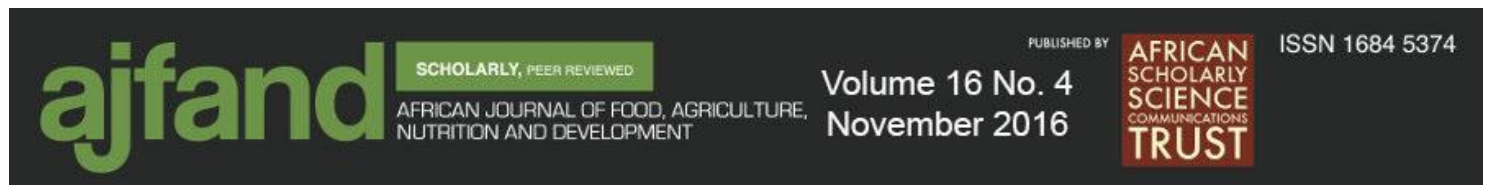

\section{INTRODUCTION}

Mortality during early developmental stages is the main constraint to reliable production of most fish species in artificial hatchery systems, especially in Malawi. External surfaces of fish eggs are easily colonized by bacteria such as Flavo-bacterrium sp., Pseudomonas sp., Aeromonas_sp. and Vibrio sp. [1,2]. Therefore, egg disinfection against bacteria and fungi, is an important standard practice in artificial hatcheries. Egg disinfection prevents transfer of pathogens from broodstock to eggs [3].

Chemical egg treatments can be more favorable as compared to the more effective but costly and highly hazardous Ultra-Violet (UV) [4]. Many chemicals have been used to disinfect eggs in aquaculture, including; hydrogen peroxide, potassium permanganate solution, sodium chloride, formaldehyde (formalin), sodium hypochlorite, chloramines$\mathrm{T}$, buffodine, glutaraldehyde, bronopol, povidone-iodine, ozone, with varying degrees of efficacy $[3,5,6,7,8]$. However, some chemicals used for disinfecting fish and fish eggs are known to also have toxic effects on the fish and fish eggs and pause a risk to human health. For example, Malachite green has been reported to have residual impurities that could prove to be more or less toxic [9]. For that reason, many countries banned its use in food-fish production industry [10]. Potassium permanganate has been widely used as an effective egg treatment chemical in fish hatcheries. However, according to the University of Florida's IFAS report of 2002, potassium permanganate non-selectively oxidizes organic matter including mucus and gill tissue in fish. Furthermore, it can cause undesirable water color changes, when used in aquaculture [11]. Toxicity of chemicals used for treating fish and fish eggs varies with fish species [12]. Common table salt, sodium chloride, has been successfully used in disinfection of eggs in certain fishes, as well as treating oomyceticidal skin damage in fish $[13,14]$. In the past, common salt was dubbed the "aspirin of aquaculture" for its common use in aquaculture [15]. Salt has many uses in aquaculture [16]. These include egg disinfection, treatment of sliminess of skin in early stages of Pillularis and velvet diseases and ectoparasites such as skin flukes (Gyrodactylus), anchor worms and fish lice [14,17]. It can also be used to treat freshwater parasite Oodinium, external parasites and monogenetic trematodes [18, 19].

In most hatcheries in Malawi, Tilapia eggs are seldom disinfected due to scarcity of chemicals and high costs. This has often resulted in high mortality rates of up to 90$100 \%$, in some cases. Oreochromis karongae is one of the potential Tilapia species for aquaculture but is often associated with high egg mortalities in hatcheries. The species already has low fecundity and efforts to find affordable measures to prevent high mortalities in early developmental stages is fundamental to successful production of $O$. karongae seed [20]. Therefore, the purpose of this study was to assess comparative effectiveness of a more affordable and potentially less toxic chemical, sodium chloride, to other chemicals currently used in Malawi, namely potassium permanganate and formalin, on reducing mortality and enhancing hatching of $O$. karongae eggs in a recirculating incubation system. 


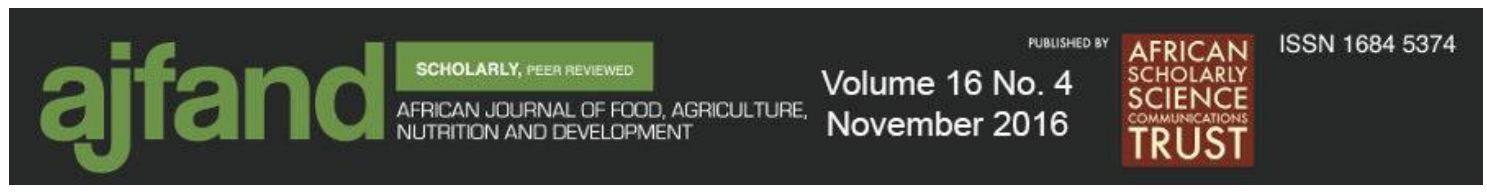

\section{MATERIALS AND METHODS}

The research was conducted at the National Aquaculture Center, Domasi, Zomba, Malawi. The station is under the Department of Fisheries of the Ministry of Agriculture and Food Security. A total of five treatments were conducted, which included immersion of $O$. karongae eggs for five minutes in $50 \mathrm{ml}$ solutions of (1) $50 \mathrm{mg} / \mathrm{l}$ potassium permanganate (P50), (2) $500 \mathrm{mg} / \mathrm{l}$ formalin (F500), (3) $1000 \mathrm{mg} / \mathrm{l}$ sodium chloride (NaCl1000), (4) $5000 \mathrm{mg} / \mathrm{l}$ sodium chloride ( $\mathrm{NaCl} 5000)$, and (5) control (CONTR.) with no chemical treatment, respectively. The levels of disinfectants were adopted from similar studies which were carried out on different species [1, 3, 14]. The chemical concentrations were prepared using standard procedures in the laboratory. The treatment levels were chosen as they are either standard practice in laboratories or have been used in similar experiments $[5,6,7]$. Therefore, prior toxicity test was not conducted. Stage II eggs were in abundance and were separated, counted and assigned to the treatments in 1.2 liter incubation jars in a re-circulating system with water flow rate of $0.17 \mathrm{l} / \mathrm{s}$ and 10 $\%$ daily water replacement. Two hundred (200) eggs of $O$. karongae were carefully added to each incubation jar. The hatching experiment was carried out over a period of 14 days in October, 2012.

Temperature, $\mathrm{pH}$ and dissolved oxygen were measured three times a day at 8 hour intervals, using a water checker. Water samples were collected in $500 \mathrm{ml}$ plastic bottles twice a week for ammonia analysis (Titration method). Egg development was monitored four times daily, and stage advancement was confirmed through observations under the light microscope $(\times 40)$ and time was recorded. Time taken for eggs to hatch was computed in data sheet/file. All data were entered into data sheet/file and exported to SPSS 16.0 for analysis. Percent data were arcsine transformed for analysis, and means were back-transformed. Duncan's Multiple Range Test (DMRT) was used to separate means which were significantly different. Other non-normally distributed count data were log-transformed for analysis of variance.

\section{RESULTS}

Total mortality was significantly lower in P50 (4.50 $\pm 1.89 \%), \mathrm{NaCl} 1000(5.78 \pm 3.26 \%)$ and F500 $(9.67 \pm 3.22 \%)$, than in the control $(52.67 \pm 8.29 \%)$ and $\mathrm{NaCl} 5000$ $(55.33 \pm 15.17 \%)(\mathrm{p}<0.05)$. Hatchability was also higher in P50 $(95.50 \pm 1.89 \%)$ and F500 $(90.33 \pm 3.22 \%)$, than in the control $(47.33 \pm 8.29 \%)$ and $\mathrm{NaCl} 5000(44.67 \pm 15.17 \%)$ ( $\mathrm{p}<0.05)$. However, hatchability in $\mathrm{NaCl} 1000(65.67 \pm 27.96 \%)$, was not significantly different $(\mathrm{p}>0.05)$ from F500 $(90.33 \pm 3.22 \%)$. Hatching period was not significantly different ( $p>0.05)$ across treatments (Table 1). Water quality parameters, despite being significantly different $(\mathrm{p}<0.05)$ across the treatments, were within acceptable limits for hatching conditions of Tilapia eggs. Temperature was slightly lower in $\mathrm{NaCl} 5000$ $(25.37 \pm 1.43 \%)$ and CONTR. $(25.36 \pm 2.10 \%)$, than in the rest of the treatments $(\mathrm{p}<0.05)$. Dissolved oxygen (DO) was highest in P50 $(6.95 \pm 0.03 \mathrm{mg} / \mathrm{l})(\mathrm{p}<0.05)$. DO in NaCl 1000 $(6.00 \pm 0.06 \mathrm{mg} / \mathrm{l})$ did not differ significantly from F500 $(6.60 \pm 0.10 \mathrm{mg} / \mathrm{l})$ and $\mathrm{NaCl} 5000$ $(6.58 \pm 0.18 \mathrm{mg} / \mathrm{l})(\mathrm{p}>0.05)$, which were lower than in P50 above. The lowest DO $(6.55 \pm 0.07 \mathrm{mg} / \mathrm{l})$ was recorded in the control experiment, but it was not significantly different from $\mathrm{NaCl} 5000$ and F500 (p>0.05). Ammonia was significantly higher in the 


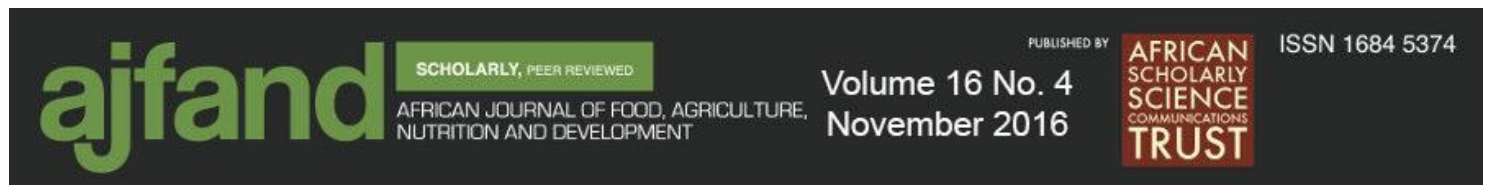

control experiment, $(0.374 \pm 0.01 \mathrm{mg} / \mathrm{l})$, followed by $\mathrm{NaCl} 1000(0.262 \pm 0.01 \mathrm{mg} / \mathrm{l})$ and F500 $(0.257 \pm 0.00 \mathrm{mg} / \mathrm{l})$, and the lowest value was in the $\mathrm{NaCl} 5000$ treatment $(0.207 \pm 0.00)(p>0.05)$. The next lower level of ammonia concentration was recorded in P50 $(0.246 \pm 0.00 \mathrm{mg} / \mathrm{l})$ and this was not significantly different from F500 (p>0.05). The highest $\mathrm{pH}$ (8.59) was recorded in the P50 treatment while the lowest was in the $\mathrm{NaCl}$ 5000 treatment $(\mathrm{p}<0.05)$ (Table 2$)$.

\section{DISCUSSION}

Findings in this study have shown that treating Oreochromis karongae eggs by immersing them in $1000 \mathrm{mg} / \mathrm{l} \mathrm{NaCl}$ and $50 \mathrm{mg} / \mathrm{l}$ permanganate solution for 5 minutes before incubation, resulted in significantly low mortality levels of eggs and larvae (4.50 and $5.78 \%$, respectively). Egg treatment in $500 \mathrm{mg} / \mathrm{l}$ formalin solution was almost half as effective as permanganate and sodium chloride concentrations above. These results are comparable with findings from studies conducted on other freshwater and marine fishes, although at different treatment periods. For example, mortalities of $21 \%$ were observed in California yellowtail (CYT; Seriola lalandi), white seabass (WSB; Atractoscion nobilis) and California halibut (HA; Paralichthys californicus) eggs at both 100mg/l formalin (60 minutes) and 1000mg/l formalin treatments (15 minutes) [3]. Formalin has also been successfully used in the treatment of cobia, rainbow trout eggs, at dosages ranging between 100 and $1500 \mathrm{mg} / \mathrm{l}$ for 60 to 15 minutes, respectively [21]. In this study, preliminary trials showed very low survival of eggs when immersed in each of the three solutions at longer periods of 15 and 60 minutes which, in agreement with others, suggests that combination of concentration and exposure times determine the effectiveness of a chosen chemical treatment agent [22]. Sodium chloride, potassium permanganate and formalin results obtained in this study are also comparable to idophor treatment in which mortality was recorded at $11.85 \%$ in Seriola lalandi [3]. However, despite being effective in killing salmonid bacterial and viral pathogens infections, iodine has high potency of toxicity [23]. Significant reduction was observed in hatchability of red porgy and white-sea bream eggs treated with $100 \mathrm{mg} / \mathrm{l}$ of iodine at 15 minutes exposure [24]. Nevertheless, effectiveness of treatment chemicals, dosages and exposure time differs from species to species [3].

While this study found significant differences in hatchability, others did not find any in Oncorhynchus mykiss eyed eggs treated with different concentrations of formalin (500 and $200 \mathrm{mg} / 1$, for 60 and 15 minutes, respectively) and hydrogen peroxide (500mg/l for 15 minutes) [25]. Similar to findings in this study, although in a different species, higher hatchability $(96.7 \%)$ was observed in catfish, Clarias gariepinus, in eggs treated with $2 \mathrm{mg} / \mathrm{l}$ potassium permanganate, for 30 minutes, than those treated with formalin, sodium chloride and hydrogen peroxide against saprolegniosis [26]. However, considering that in this study hatchability was higher $(74.6 \%)$ at a lower concentration of $1000 \mathrm{mg} / \mathrm{l}$ than at higher concentration of $5000 \mathrm{mg} / \mathrm{l}$, which was $45.8 \%$, it is possible that at much lower concentrations as used in other studies, even higher hatchability would be realized [22]. Apart from being effective in treating live fish, such as reducing bacterial load during transportation of fingerlings of O.niloticus, sodium chloride was also found to be effective in preventing high mortalities during egg development in O. karongae. However, different salt concentrations and exposure time may reveal more options for 


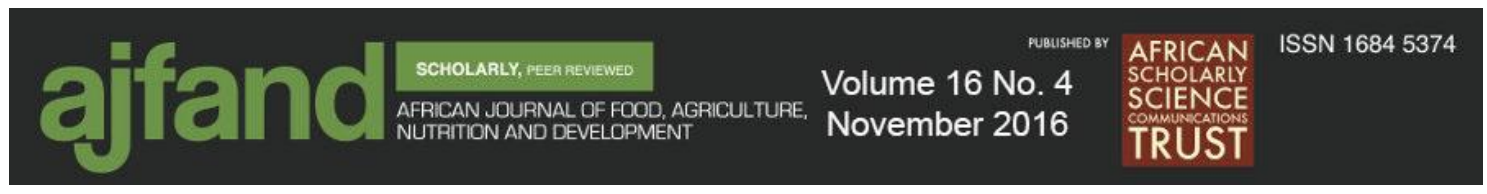

Tilapia egg treatments as such factors affect effectiveness of disinfection [27]. The differences in some water quality parameters are not attributable to the significant changes in mortality and hatchability as they were small and most values were within tolerable ranges for Tilapia [28].

\section{CONCLUSION}

In conclusion, low concentrations of Sodium Chloride, which is a more affordable and safer chemical disinfectant, can be used to treat $O$. karongae eggs and prevent high mortalities as equally as formalin and potassium permanganate. There is potential for fish hatcheries to increase $O$. karongae fry production through the practice of preincubation egg treatment. Thus, the findings from the research will be useful to hatchery operators even in the absence of microbial assays. However, future research should include microbiological assays to validate the apparent effectiveness found in this study and identify the key microbes that cause mortalities in eggs and fry that hatches out of the eggs during incubation.

\section{ACKNOWLEDGEMENTS}

The authors would like to acknowledge the invaluable support rendered by the management and technical staff of the National Aquaculture Center of the Fisheries Department, Ministry of Agriculture and Food Security, of Malawi Government, where the research was conducted. Special thanks are also due to the Regional Universities Forum for Capacity Building in Agriculture (RUFORUM) for funding the research with support from the International Development Research Center (IDRC) of Canada. 


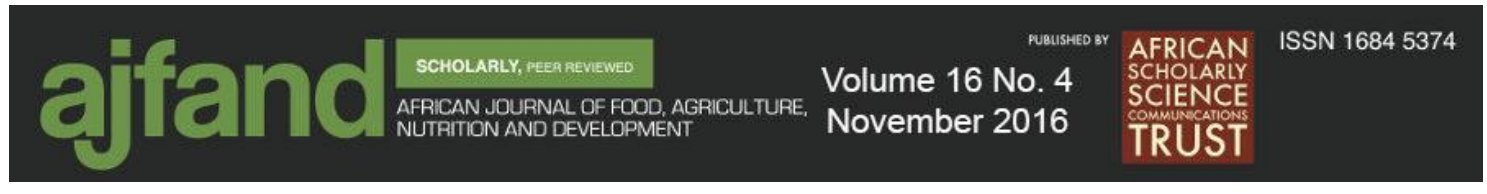

Table 1: Hatchability attributes (Mean \pm SE) of $O$. karongae eggs incubated in a re-circulating system (from stage 1 to stage 5-egg yolk exhaustion)

\begin{tabular}{lccc}
\hline Treatment & $\begin{array}{c}\text { Mean Hatching Period } \\
(\text { days })\end{array}$ & $\begin{array}{c}\text { Total mortality } \\
(\%)\end{array}$ & $\begin{array}{c}\text { Mean Hatchability } \\
(\%)\end{array}$ \\
\hline P50 & $10.67 \pm 0.00^{\mathrm{a}}$ & $4.50 \pm 1.89^{\mathrm{a}}$ & $95.50 \pm 1.89^{\mathrm{b}}$ \\
$\mathrm{F} 500$ & $10.33 \pm 0.00^{\mathrm{a}}$ & $9.67 \pm 3.22^{\mathrm{a}}$ & $90.33 \pm 3.22^{\mathrm{b}}$ \\
$\mathrm{NaCl}$ & $10.67 \pm 0.00^{\mathrm{a}}$ & $5.78 \pm 3.26^{\mathrm{a}}$ & $65.67 \pm 27.86^{\mathrm{ab}}$ \\
1000 & & \\
$\mathrm{NaCl}$ & $10.00 \pm 0.00^{\mathrm{a}}$ & $55.33 \pm 15.17^{\mathrm{b}}$ & $44.67 \pm 15.17^{\mathrm{a}}$ \\
5000 & & & \\
$\mathrm{CONTR}$ & $10.00 \pm 0.00^{\mathrm{a}}$ & $52.67 \pm 8.29^{\mathrm{b}}$ & $47.33 \pm 8.29^{\mathrm{a}}$ \\
& & & \\
\hline
\end{tabular}

${ }^{\mathrm{ab}}$ Values with the same letter in the same column are not significantly different $(\mathrm{p}>0.05)$ 


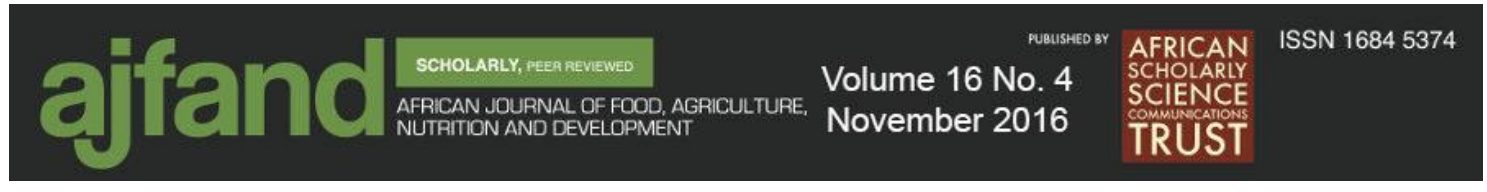

Table 2: Water quality parameters (Mean \pm SE) for incubation of stage II eggs of Oreochromis karongae eggs incubated in a re-circulating system

\begin{tabular}{lcccc}
\hline Treatment & $\begin{array}{c}\text { Temperature } \\
(\mathrm{C})\end{array}$ & $\begin{array}{c}\text { Dissolved Oxygen } \\
(\mathrm{mg} / \mathrm{L})\end{array}$ & $\mathrm{pH}$ & Ammonia (mg/L) \\
\hline P50 & $25.6 \pm 1.0 \mathrm{~b}$ & $6.95 \pm 0.03 \mathrm{~b}$ & $8.6 \pm 0.02 \mathrm{~d}$ & $0.25 \pm 0.00 \mathrm{~b}$ \\
$\mathrm{~F} 500$ & $25.6 \pm 1.5 \mathrm{~b}$ & $6.60 \pm 0.10 \mathrm{ab}$ & $8.5 \pm 0.01 \mathrm{c}$ & $0.26 \pm 0.00 \mathrm{bc}$ \\
$\mathrm{NaCl} \mathrm{1000}$ & $25.6 \pm 2.4 \mathrm{~b}$ & $6.90 \pm 0.06 \mathrm{~b}$ & $8.6 \pm 0.01 \mathrm{~d}$ & $0.26 \pm 0.01 \mathrm{c}$ \\
$\mathrm{NaCl} \mathrm{5000}$ & $25.4 \pm 1.4 \mathrm{a}$ & $6.58 \pm 0.18 \mathrm{ab}$ & $7.9 \pm 0.00 \mathrm{a}$ & $0.21 \pm 0.00 \mathrm{a}$ \\
$\mathrm{CONTR}$. & $25.4 \pm 2.1 \mathrm{a}$ & $6.55 \pm 0.07 \mathrm{a}$ & $8.0 \pm 0.02 \mathrm{~b}$ & $0.37 \pm 0.01 \mathrm{~d}$
\end{tabular}

a,b,c,d Values with the same letter in the same column are not significantly different $(\mathrm{p}>0.05)$ 


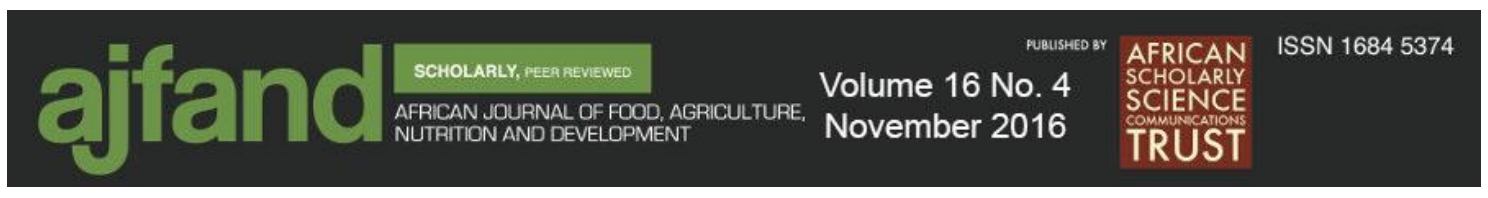

\section{REFERENCES}

1. Miguez B and MP Combarro Disinfection of striped trumpeter (Latris lineate) eggs with glutaraldehyde. Aquaculture International, 2003; 9: 189-196.

2. Madsen L, Moller JD and I Dalsgaard Flavobacterium psychrophilum in rainbow trout, Oncorhyncus mykiss (Walbaum) hatcheries: studies on broodstock, eggs, fry and environment. Journal of Fish Diseases, 2005; 28: 3947.

3. Stuart K, Keller M and M Drawbridge Efficacy of formalin and povidoneiodine disinfection techniques on the eggs of three marine finfish species. Aquaculture Research, 2010; 41: e838-e843.

4. Don J, Koiller M, Yeheskel $\mathbf{O}$ and RR Avtalion Increased Tilapia Embryo Viability Using Ultraviolet Irradiation in a Closed Recirculatung Zuger-Bottle System. Aquacultural Engineering, 1987; 6: 69-74.

5. Salvesen I and $O$ Vadstein Surface disinfection of eggs from marine fish: evaluation of four chemicals. Aquaculture International, 1995; 3:155-171.

6. Salvesen I, Oie G and O Vadstein Surface disinfection of Atlantic halibut and turbot eggs with glutaraldehyde: evaluation of concentrations and contact times. Aquaculture International, 1997; 5: 249-258.

7. Birkbeck TH, Reid HI, Darde B and AN Grant Activity of bronopol (Pycezes) against bacteria cultured from eggs of halibut, Hippoglossus hippoglossus and cod, Gadus morhua. Aquaculture, 2006; 254: 125-128.

8. Buchan KAH, Martin-Robichaud DJ, Benfey TJ, MacKinnon AM and L Boston The efficacy of ozonated seawater for surface disinfection of haddock (Melanogrammus aeglefinus) eggs against piscine nodavirus. Aquacultural Engineering, 2006; 35: 102-107.

9. Sudova E, Machova J, Svobodova $Z$ and $\mathbf{T}$ Vesely Negative effects of malachite green and possibilities of its replacement in the treatment of fish eggs and fish: a review. Veterinarni Medicina, 2007; 12: 527-537.

10. Treves-Brown KM Applied Fish Pharmacology. Kluwer Academic Publishers, Dordrecht, 2000: 1-36.

11. University of Florida, IFAS Extension Use of Potassium Permanganate to control external infections of ornamental fish. Fisheries and Aquatic Sciences Department, Florida Cooperative Extension Service, Institute of Food and Agricultural Sciences, University of Florida. Gainesville, 2002, 32611. http://edis.ifas.ufl.edu Accessed on 20 March, 2013. 


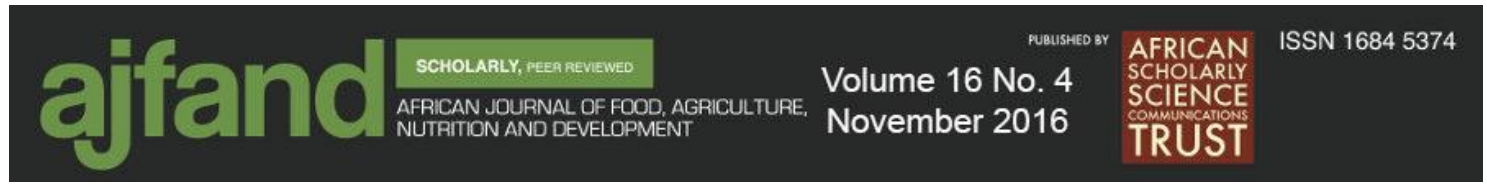

12. Zahran $\mathbf{E}$ and $\mathbf{E}$ Rish Protective role of adjuvant and potassium permanganate on oxidative stress response of Nile Tilapia (Oreochromis niloticus) challenged with Saprolegnia ferax. SpringerPlus, 2013; 2: 94. Doi: 10.1186/2193-1801-294.

13. Straus DL, Hossain MM and TG Clark Copper sulfate toxicity to two isolates of Ichthyophthirius multifilisi relative to alkalinity. Dis Aquat Org, 2009; 83:3.

14. Swann L and S Fitzgerald Use and application of salt in aquaculture, 1993. http://muextension.missouri.edu/explore/iscpubs/mx0393.htm. Accessed on 20 March, 2013.

15. Francis-Floyd $\mathbf{R}$ The Use of Salt in Aquaculture Edis 1995. http://edis.ifas.ufl.edu/BODY_VM007. Accessed on 20 March, 2013.

16. Van Duijn C Jr Diseases of Fishes. 3rd edition. Butterworth and Co. Ltd., London. 1973:372.

18. Baticados MCL and JO Paclibare The use of chemotherapeutic agents in aquaculture in the Philippines. pp. 531-546. In: Sheriff, M., Subasinghe, R P., and Arthur, J.R. (eds.). Diseases in Asian Aquaculture I. Fish Health Section, Asian Fisheries Society, Manila, Philippines, 1992: 587.

19. Plumb JA Disease control in aquaculture. pp. 3-17. In: Sheriff, M., Subasinghe, R. P., and Arthur, J. R. (eds.). Diseases in Asian Aquaculture I, Fish Health Section, Asian Fisheries Society, Manila, Philippines. 1992, 587.

20. Msiska OV and BA Costa-Pierce Maturity and gonad changes of Oreochromis (Nyasalapia) karongae raised in fish ponds in Malawi. Journal of Applied Itchthyology, 1999; 15: 97-103.

21. Benetti DD, Orhun MR, Sardenberg B, O'Hanlon B, Welch A, Hoenig R, Zink I, Rivera JA, Denlinger B, Bacoat D, Palmer K and F Cavalin Advances in hatchery and grow-out technology of cobia Rachycentron canadum (Linnaeus). Aquaculture Research, 2008; 39: 701-711.

22. Schreier TM, Rach JJ and GE Howe Efficacy of formalin, hydrogen-peroxide, and sodium-chloride on fungal-infected rainbow-trout eggs: Aquaculture, 1996; 140 (4): 323-331.

23. Magondu EW, Rasowo J, Oyoo-Okoth E and H Charo-Karisa Evaluation of sodium chloride $(\mathrm{NaCl})$ for potential prophylactic treatment and its short-term toxicity to African catfish Clarias gariepinus (Burchell 1822) yolk-sac and swimup fry. Aquaculture 2011; 319: 307-31.

24. Amend DF Comparative toxicity of two iodophors to rainbow trout eggs. Transactions of the American Fisheries Society, 1974; 103:73-78. 


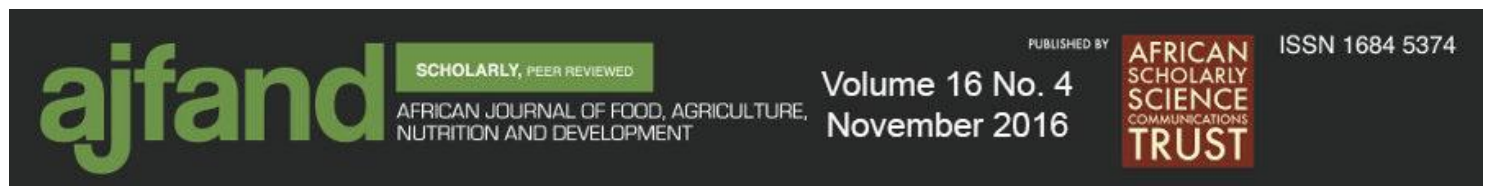

25. Katharios P, Agathaggelou A, Paraskevopoulos S and CC Mylonas Comparison of iodine and glutaraldehyde as surface disinfectants for red porgy (Pagrus pagrus) and white sea bream (Diplodus sargus sargus) eggs. Aquaculture Research, 2007; 38: 527-536.

26. Wyatt $\mathbf{T}$ and A Barkoh Investigation of formalin and hydrogen peroxide treatments to control fungus on Florida Largemouth Bass eggs. Management Data Series No. 216, 2003.

27. Rasowo J, Okoth OE and CC Ngugi Effects of formaldehyde, sodium chloride, potassium permanganate and hydrogen peroxide on hatch rate of African catfish Clarias gariepinus eggs. Aquaculture, 2007; 269(1-4):271-277.

28. Beveridge MCM and BJ McAndrew Tilapias: Biology and Exploitation. Kruwer Academic Press Publishers. Dordrecht, the Netherlands, 2000:505. 